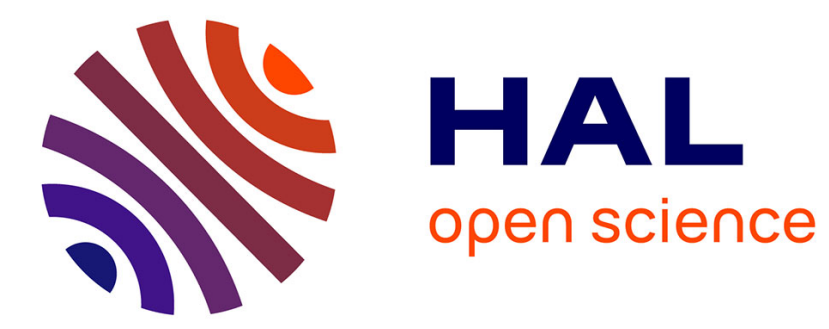

\title{
MÉTHODES DE CALCUL DIGITAL
}

J. Connes, Pierre Connes

\section{To cite this version:}

J. Connes, Pierre Connes. MÉTHODES DE CALCUL DIGITAL. Journal de Physique Colloques, 1967, 28 (C2), pp.C2-57-C2-57. 10.1051/jphyscol:1967211 • jpa-00213189

\section{HAL Id: jpa-00213189 https://hal.science/jpa-00213189}

Submitted on 1 Jan 1967

HAL is a multi-disciplinary open access archive for the deposit and dissemination of scientific research documents, whether they are published or not. The documents may come from teaching and research institutions in France or abroad, or from public or private research centers.
L'archive ouverte pluridisciplinaire HAL, est destinée au dépôt et à la diffusion de documents scientifiques de niveau recherche, publiés ou non, émanant des établissements d'enseignement et de recherche français ou étrangers, des laboratoires publics ou privés. 


\title{
MÉTHODES DE CALCUL DIGITAL
}

\author{
J. CONNES \\ Observatoire de Meudon, 92-Meudon, France \\ P. CONNES, \\ Laboratoire Aimé Cotton, CNRS, 92-Bellevue, France
}

\begin{abstract}
Résumé. - Les spectres planétaires, décrits dans une autre communication, sont calculés à partir d'interférogrammes échantillonnés en $M=15000$ points (valeur maximum) enregistrés entre les valeurs extrêmes de la différence de marche $\Delta=0$ et $\Delta=\Delta \max$. Aucun échantillon ne coïncidant rigoureusement avec le point zéro il est nécessaire de déterminer par le calcul (avec une précision de l'ordre de l'angström) la distance entre le premier échantillon et le vrai zéro, puis de calculer un interférogramme " secondaire ) par interpolation de l'interférogramme enregistré ( primaire »; l'opération utilise une convolution. On calcule ensuite la transformée en cosinus, en une série de points ( primaires ) du spectre dont l'écart est choisi légèrement inférieur à la limite de résolution. Des points " secondaires ) 5 à 10 fois plus serrés sont ensuite calculés par convolution, en même temps qu'est introduite l'apodisation désirée.

Pour réduire le temps de calcul de la transformée de Fourier (proportionnel à $M^{2}$ par les méthodes conventionnelles), on peut appliquer la méthode suivante : le spectre est divisé en $k$ tranches égales et les $M / k$ points primaires correspondant à chaque tranche sont calculés à partir des $M / k$ échantillons d'un interférogramme déduit du précédent par convolution, et dans lequel l'écart entre échantillons est multiplié par $k$. Pour chaque tranche du spectre le temps de calcul est proportionnel à $M^{2} / k^{2}$, et pour le spectre entier à $M^{2} / k$, donc réduit d'un facteur $k$.

[Depuis le Colloque nous avons d'autre part adapté la méthode de Cooley et Tuckey (Math. of Comput., 1965, 19, 297), signalée par M. Forman dans sa communication, à un ordinateur 7040 muni de 4 dérouleurs de bandes et avons pu traiter des interférogrammes contenant jusqu'à $M=58000$ échantillons (à paraître au Journal de Physique)].

La description complète des méthodes utilisées doit paraître comme seconde partie de l'article Near Infrared Planetary Spectra by Fourier Spectroscopy, J. Opt. Soc. Amer., 1966, 56, 896.
\end{abstract}

Abstract. - The planetary spectra described in another communication are computed from interferograms with $M=15000$ samples (or less), recorded between $\Delta=0$ and $\Delta=\Delta$ max. Since no sample coincides with the zero point it is necessary first to compute (with an accuracy of the order of $1 \AA$ ) the distance between the first sample and the true zero, then to compute a "secondary " interferogram by interpolation of the " primary 》 recorded interferogram; this is done by convolution. One computes then the cosine transform for a set of ( primary ) spectral samples, the separation of which is taken slightly less than the resolution. A set of between 5 and 10 times as many ( secondary ) spectral samples is then computed, again by a convolution; the necessary apodization is simultaneously performed.

In order to reduce the computation time of the Fourier transform (proportional to $M^{2}$ by standard methods) it is possible to apply the following principle : the spectrum is divided into $k$ equal sections, and the $M / k$ primary spectral samples of each slice are computed from the $M / k$ samples of an interferogram deduced from the recorded one by convolution, and in which the sample separation is multiplied by $k$. For each section the computation time is proportional to $M^{2} / k^{2}$, and for the entire spectrum to $M^{2} / k$; it is thus reduced by a factor of $k$.

[After the Colloquium we have also adapted the Cooley-Tuckey method (Math. of Comput., $1965,19,297)$, discussed by $\mathrm{M}$. Forman in his communication, to a 7040 computer with 4 tape transports; thus we have been able to transform interferograms with up to 58000 samples (to be published, $J$. de Physique).

The complete description of the methods we use will be published as Part II of the paper Near Infrared Planetary Spectra by Fourier Spectroscopy, JOSA, 1966, 56, 896. 